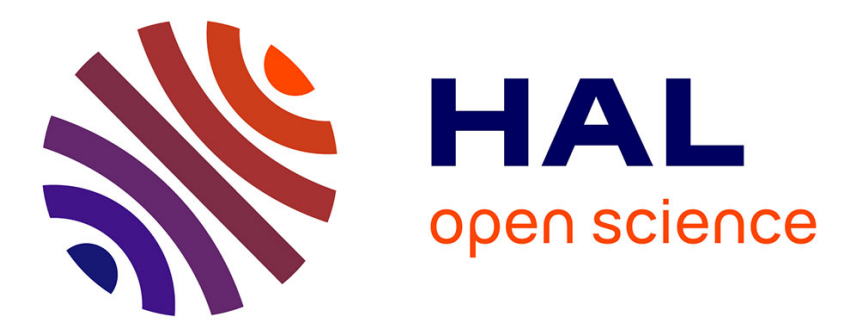

\title{
Trace elements in tissues of white chinned-petrels (Procellaria aequinoctialis) from Kerguelen waters, Southern Indian Ocean
}

Caio V. Z. Cipro, Yves Cherel, Florence Caurant, Pierre Miramand, Paula

Mèndez-Fernandez, Paco Bustamante

\section{To cite this version:}

Caio V. Z. Cipro, Yves Cherel, Florence Caurant, Pierre Miramand, Paula Mèndez-Fernandez, et al.. Trace elements in tissues of white chinned-petrels (Procellaria aequinoctialis) from Kerguelen waters, Southern Indian Ocean. Polar Biology, 2014, 37 (6), pp.763-771. 10.1007/s00300-014-1476-z . hal-00990701

\section{HAL Id: hal-00990701 \\ https://hal.science/hal-00990701}

Submitted on 13 May 2014

HAL is a multi-disciplinary open access archive for the deposit and dissemination of scientific research documents, whether they are published or not. The documents may come from teaching and research institutions in France or abroad, or from public or private research centers.
L'archive ouverte pluridisciplinaire HAL, est destinée au dépôt et à la diffusion de documents scientifiques de niveau recherche, publiés ou non, émanant des établissements d'enseignement et de recherche français ou étrangers, des laboratoires publics ou privés. 
Trace elements in tissues of white-chinned-petrels (Procellaria aequinoctialis) from Kerguelen waters, Southern Indian Ocean

Caio V. Z. Cipro ${ }^{*}, 1,2$, Yves Cherel $^{2}$, Florence Caurant ${ }^{1}$, Pierre Miramand ${ }^{1}$, Paula MéndezFernandez ${ }^{1}$, Paco Bustamante ${ }^{1}$

${ }^{1}$ Littoral Environnement et Sociétés (LIENSs), UMR 7266, CNRS-Université de La Rochelle, 2 rue Olympe de Gouges 17042 La Rochelle Cedex 01, France

${ }^{2}$ Centre d'Etudes Biologiques de Chizé, UPR 1934 du Centre National de la Recherche Scientifique, BP 14, 79360 Villiers-en-Bois, France

\footnotetext{
* Corresponding author. Email address: caiovzc@gmail.com
} 


\begin{abstract}
:
The use of seabirds to assess marine contamination by trace elements in areas remote from pollutant emission points has already been done at various latitudes. Nevertheless, little information is available concerning the Southern Indian Ocean. Determining the contaminants levels there appears necessary not only due to several deleterious effects reported in literature, but also as previous studies have highlighted elevated concentrations of cadmium (Cd) and mercury $(\mathrm{Hg})$ in mollusks, crustaceans and fish. Within this context, the white-chinned-petrel appears as a key species due to its lifespan, diet and trophic position. Thirty three accidentally killed (collision with lights/bycatch in longline vessels) individuals collected in Kerguelen waters were analysed for $\mathrm{Cd}$, copper $(\mathrm{Cu}), \mathrm{Hg}$, selenium $(\mathrm{Se})$ and zinc $(\mathrm{Zn})$ in liver, kidney, pectoral muscle, feathers and for mature males, testis. Elevated $\mathrm{Hg}$ concentrations (average: $58.4 \mu \mathrm{g} \mathrm{g}^{-1} \mathrm{dw}$ in liver) are likely due to the presence of mesopelagic prey in the diet of $P$. aequinoctialis. Cd concentrations (average of $65.7 \mu \mathrm{g} \mathrm{g}^{-1} \mathrm{dw}$ in kidney) can be attributed to a high level of fisheries offal consumption, as well as crustacean and squid ingestion. Correlation of $\mathrm{Hg}$ with Se indicates its detoxification by co-precipitation, and correlation of $\mathrm{Cd}$ with $\mathrm{Zn}$ suggests its displacement by $\mathrm{Cd}$ on metallothioneins binding sites. This work also indirectly confirms ecological data (range and diet composition) from the wintering period of the species, which is rather scarce. Seasonal diet change and moulting accounted more for the obtained results than sex of the birds.
\end{abstract}

Keywords: Heavy metals, seabirds, Procellariiformes, Southern Ocean, subantarctic islands 


\section{INTRODUCTION}

Contamination of the marine environment is a problem of concern at the worldwide scale. Oceanic ecosystems are often considered less impacted than coastal ones because they are not directly submitted to river influxes, runoff, and point-source pollution from urban, industrial and agricultural emissions (Mailman, 1980). Nonetheless, many of these contaminants, e.g. persistent organic pollutants or mercury $(\mathrm{Hg})$ are transported by the atmosphere all over the world and they deposit into oceanic environments (Fitzgerald and Engstrom, 1998). In the aquatic environment, contaminants such as trace elements are more mobile than in terrestrial ones (Selin, 2009), and species foraging in these environments could, therefore, be considered more vulnerable.

Trace elements encompass essential elements involved in physiological and biochemical processes (Abdulla and Chmielnicka, 1990) that can however be toxic when exposure and assimilation are excessive. Others, such as cadmium (Cd) and $\mathrm{Hg}$, are nonessential elements that are potentially toxic even at relatively low concentrations. Exposure of marine organisms is governed by various factors, including foraging location and trophic position (Anderson et al., 2010). Among trace elements, $\mathrm{Cd}$ and $\mathrm{Hg}$ are known to bioaccumulate in food webs, resulting to high concentrations in long-lived top predator species such as marine birds. This process is particularly exacerbated at high latitudes (Dietz et al., 1998; Elliott and Scheuhammer, 1997), where the baseline concentrations are probably higher than at more temperate latitudes (Bocher et al., 2003). Food constitutes the main pathway of exposure of seabirds to contaminants (e.g., Ochoa-acuña et al., 2002). Nevertheless, numerous factors such as phylogeny, moult pattern, sex, life span and diet composition are likely to influence trace element bioaccumulation in seabird tissues, with $\mathrm{Cd}$ and $\mathrm{Hg}$ concentrations showing the largest variation among seabird species (Stewart et al., 1999; Walsh, 1990). Because seabirds are long-lived species situated at the top of the food 
web, they are also submitted to the process of biomagnification of contaminants (Furness and Camphuysen, 1997). For these reasons, marine birds are considered to be useful bioindicators of environmental contamination (Furness and Camphuysen, 1997; Monteiro and Furness, 1995). They seem to be particularly appropriate to survey the health status of marine ecosystems as they generally display lower coefficients of variation of contaminant levels than fish or marine mammals (Gilbertson et al., 1987). Furthermore, they are reflecting large areas integrating contaminants even from remote places that would be otherwise difficult to sample (Stewart et al. 1999; Carravieri et al., 2013). The use of seabirds to monitor marine contamination by trace elements in areas remote from pollutant emission points has already been done at various latitudes (Anderson et al., 2010; Fitzgerald and Engstrom, 1998; Kojadinovic et al., 2007). However, information concerning the Southern Indian Ocean is still scarce. Only one study reported trace element concentrations in liver, kidney and muscle for 5 small petrels, prions and diving-petrels from the Kerguelen Islands, all of them mainly feeding on zooplankton (Bocher et al. 2003). The study highlighted that the diet was a key factor driving the exposure and trace element levels in the tissues of these birds. More recently, $\mathrm{Hg}$ concentrations were determined in feathers from a large number of species, revealing a strong influence of the feeding behaviour on $\mathrm{Hg}$ concentrations (Blévin et al., 2013; Carravieri et al., 2013). Identification of high levels of $\mathrm{Cd}$ and $\mathrm{Hg}$ in mollusks, crustaceans and fish from the Kerguelen waters (Bocher et al., 2003; Bustamante et al., 2003, 1998) would result in elevated exposure of seabirds. Moreover, several deletery effects of such elements have already been reported in birds, for instance: decrease in egg laying, egg hatchability and increase in embryonic mortality; and besides neurotoxicity, there is also evidence for immunotoxic effects, such as decreased immune response and histological changes (Scheuhammer et al., 2007; Goutte et al. in press) and several endocrine effects as well (e.g. Tan et al., 2009; Tartu et al. 2013). In this context, the monitoring of the 
contaminants in the Southern Indian Ocean appears therefore a matter of importance.

Procellaria aequinoctialis, even though one of the most abundant seabirds in the Southern Ocean is classified as Vulnerable in the IUCN red list since literature presents historical declines of populations within the Southern Ocean, namely at Crozet (Barbraud et al. 2008) and South Georgia (Berrow et al. 2000), but not conclusively in Kerguelen Islands (Barbraud et al. 2009). Very high rates of incidental mortality in longline fisheries have been recorded in recent years (Birdlife International, 2013). The probability that these circumstances will continue and its susceptibility to predation and the degradation of breeding habitat indicate that a rapid and on-going population decline is likely (Birdlife International, 2013). Specifically for the Kerguelen waters, the mortality caused by fisheries constitutes a serious threat for $P$. aequinoctialis at least at the regional scale of the Southern Indian Ocean (Barbraud et al., 2009). A similar conclusion was taken for the Crozet Islands population, even though estimates of the number of birds killed by the longline fishing vessels remained within the threshold levels (estimated around 8000 individuals per annum in this specific case) after 2003 (Barbraud et al., 2008). Association to commercial fisheries is due whether because $P$. aequinoctalis target the same areas of high productivity than fishermen and/or because fisheries appear to represent an additional potential food source for these opportunistic seabirds in the form of offal and discards of non-target species (Delord et al., 2010). In their wintering grounds, i.e., the eastern boundary upwelling system of the Benguela current (Péron et al., 2010), P. aequinoctalis population's from the Kerguelen waters mainly feed on offal, i.e., fish heads and guts scavenged from commercial trawlers (Jackson, 1988). Nevertheless, their diet also includes "natural" pelagic fish prey, crustaceans and cephalopods, in this order. Prey given to chicks during the breeding season is mainly composed of fish, followed by cephalopods and then crustaceans (Delord et al. 2010). In the Crozet Islands (3.2 degrees north from Kerguelen), the diet of $P$. aequinoctalis is somewhat 
similar with fish prevailing, especially mesopelagic species (Catard et al., 2000; Connan et al., 2007; Ridoux, 1994). However, crustaceans and cephalopods are important prey as well.

In this study, we examine the levels of $\mathrm{Cd}$, copper $(\mathrm{Cu}), \mathrm{Hg}$, selenium $(\mathrm{Se})$, and zinc (Zn) concentrations in the feathers, liver, kidney and muscle tissues (and also testis in a smaller extent) of the white-chinned-petrel $P$. aequinoctialis from Kerguelen waters using only incidentally killed animals. The second objective of this work was to make the relationship between trace element levels in internal tissues, reflecting the risk of toxicity for the birds, and their levels in the feathers that, if related to the internal organs, could provide a wider non-destructive monitoring basis (Agusa et al., 2005).

\section{MATERIALS AND METHODS}

\subsection{Sampling}

Sample collection occurred from October/1998 to March/2000 at Kerguelen Archipelago, Southern Indian Ocean. Thirty three white-chinned petrels were collected as bycatch of longline fishing vessels or found recently dead on land killed following collision with the Scientific Station lights. Only intact or almost intact birds were considered for this study. The petrels were weighed in the field, immediately frozen and kept at $-20^{\circ} \mathrm{C}$ until analyses. Birds were thawed overnight and dissected for liver, kidney, muscle (pectoral), testis (only on three mature males) and body feather removal, as body feathers (mainly pectoral ones, avoiding brood patch areas) give the best measure of the mercury contamination of a bird (Furness and Camphuysen, 1997). They were also sexed by visual observation of the gonads: 6 individuals could be identified as females and 12 as males. 


\subsection{Trace element analyses}

Analyses were performed as described by Bocher et al. (2003): for $\mathrm{Cd}, \mathrm{Cu}$ and $\mathrm{Zn}$ determination, two aliquots of approximately $200-300 \mathrm{mg}$ of each homogenised dried sample were digested in $5 \mathrm{ml}$ of suprapure $14 \mathrm{~N}$ nitric acid at $60^{\circ} \mathrm{C}$ on a hot plate until the solution was clear. After evaporation, the residues were dissolved in $10 \mathrm{ml}$ of $0.3 \mathrm{~N}$ suprapure nitric acid. Trace elements were determined by flame Atomic Absorption Spectrophotometry (AAS) with a Varian spectrophotometer Spectra 250 Plus with a deuterium background correction (high $\mathrm{Cd}$ concentrations, $\mathrm{Cu}$ and $\mathrm{Zn}$ ) and by graphite furnace AAS (Hitachi Z-5000) with Zeeman background correction (low Cd concentrations and Se). Feather analyses included a previous cleaning step in order to remove surface lipids and contaminants, by using a 2:1 chloroform:methanol solution followed by two successive methanol rinses. After cleaning, body feathers were oven dried for $48 \mathrm{~h}$ at $50{ }^{\circ} \mathrm{C}$.

Mercury analysis was carried out with an Automatic Mercury Analyser spectrophotometer, ALTEC AMA 254, which does not require an acid-digestion of the samples. Aliquots ranging from 10 to $50 \mathrm{mg}$ of dried sample were directly analysed after being inserted in the oven of the apparatus. After drying, the samples were heated under an oxygen atmosphere for $3 \mathrm{~min}$, and the $\mathrm{Hg}$ liberated and subsequently amalgamated on an $\mathrm{Au}$ net. The net was then heated to liberate the collected $\mathrm{Hg}$, which was measured by AAS.

Accuracy and reproducibility of the methods were tested using dogfish liver (DOLT2) and muscle (DORM-2) and lobster hepatopancreas (TORT-2) (National Research Council, Canada) reference standards. Standard and blanks were analysed along with each set of samples and recoveries of the certified values and recoveries of the metals ranged from 92 to 105\%. Measurements were also validated by the IAEA Intercalibration Exercise (Coquery et al., 2001). Concentrations are expressed in dry weight in order to compensate eventual moisture loss during freezing and to facilitate comparison between tissues and with other 
studies. Blanks were analysed at the beginning of each set of samples and the detection limit of the method was $0.005 \mu \mathrm{g} \mathrm{g}^{-1}$ dry mass.

\subsection{Statistical analyses.}

Tests were performed using Microsoft Excel and Statsoft Statistica. Before analyses, data was checked for normality of distribution and homogeneity of variances using ShapiroWilk and Brown-Forsythe tests, respectively. Parametrical (Tukey HSD/ANOVA) and nonparametrical tests (Kruskal-Wallis/ANOVA) followed accordingly. Comparison between sexes was performed by means of Wilcoxon-Mann-Whitney test. Statistically significant results were set at $\alpha=0.05$.

\section{RESULTS}

$\mathrm{Cd}, \mathrm{Cu}, \mathrm{Hg}, \mathrm{Se}$ and $\mathrm{Zn}$ concentrations in the tissues of $P$. aequinoctialis are presented in Table 1. No significant correlations (Pearson's product-moment) were detected between tissue concentrations (both in wet weight and dry weight basis) and total body weight of the birds. The results overall showed that liver and kidney are the main sites for bioaccumulation of non essential trace elements, with mean values of $58.4 \pm 33.4 \mu \mathrm{g} \mathrm{g}^{-1} \mathrm{dw}$ of $\mathrm{Hg}$ in the liver and $65.7 \pm 22.2 \mu \mathrm{g} \mathrm{g}^{-1} \mathrm{dw}$ of $\mathrm{Cd}$ in the kidney. In these tissues, $\mathrm{Cd}$ and $\mathrm{Hg}$ concentrations were one order of magnitude higher than those of muscle and feathers, which were the only tissues that did not present statistically significant difference for both contaminants. In contrast, Cd concentrations in the testis were as high as in the kidney.

$\mathrm{Cu}$ presented similar concentrations and ranges in liver, kidney, muscle and testis. Nevertheless, $\mathrm{Cu}$ variability was always lower than $30 \%$ in the 3 former tissues whereas it 
was above $70 \%$ in the testis, mostly due to the small sampling number $(n=3)$ that precluded further statistical analyses. Feathers showed the lowest concentrations in average, but with a relatively high variability (coefficient of variation of 43\%). Se concentrations were the lowest in the liver and highest in the kidney, with average concentrations of $6.2 \pm 2.0$ and $16.1 \pm 4.8$ $\mu \mathrm{g} \mathrm{g}^{-1} \mathrm{dw}$, respectively. Nevertheless, the variation of Se concentrations remained always < $35 \%$. For $\mathrm{Zn}$, the concentrations were the lowest in muscles and highest in feathers in which the variability was relatively high (coefficient of variation of $73 \%$ ). Nevertheless, this difference was statistically significant. Only muscle and liver, and liver and kidney (paired) did not present such differences. The other tissues, liver, kidney and testis, showed similar concentrations that were intermediate between those of muscle and feathers.

Males and females have shown significant contaminant differences in only one case: Cd in muscle was higher in males. All other comparisons were not statistically significant.

Inter and intra-tissue correlations are shown in Table 2. Significant intra-tissue correlations appeared mostly within liver and kidney and to a lesser extent in muscle, whereas no correlation was found in feathers. In liver, $\mathrm{Cd}$ was positively correlated to $\mathrm{Hg}$, Se and $\mathrm{Zn}$, $\mathrm{Cu}$ was positively correlated to $\mathrm{Zn}$, and $\mathrm{Se}$ to $\mathrm{Hg}$. In kidney, Se was positively correlated to $\mathrm{Cd}, \mathrm{Cu}$ and $\mathrm{Zn}$ and $\mathrm{Zn}$ was positively correlated to $\mathrm{Cd}, \mathrm{Cu}$, and $\mathrm{Se}$. In muscle, only $\mathrm{Cu}$ was negatively correlated to $\mathrm{Zn}$ and Se positively correlated to $\mathrm{Hg}$.

Almost no significant inter-tissue correlations were detected for $\mathrm{Cu}$ and $\mathrm{Zn}$, with only concentrations in the liver being negatively correlated to those in the feathers. Significant inter-tissue correlations appear mostly between the liver and kidney for non essential elements but also for Se. Thus, Cd concentrations in the liver correlated positively with those in the kidney but negatively with those in the feathers. Concerning $\mathrm{Hg}$, concentrations in the liver positively correlated to those in kidney and in muscle. Similar correlations were found for Se, as well as a significant correlation between liver and muscle Se concentrations. 
In order to better understand detoxification processes, other correlations were also investigated for non essential elements (Fig. 1 \& 2). Figure 1 presents the liver $\mathrm{Hg}$ concentrations as a function of kidney $\mathrm{Cd}$ concentrations. The relationship between both non essential elements in their main tissues of bioaccumulation was however not significant. Figure 2 presents the molar relationship between $\mathrm{Se}$ and $\mathrm{Hg}$. It highlighted a significant increase of the number of atoms of Se with those of $\mathrm{Hg}$ in the liver, but not in the kidney.

\section{DISCUSSION}

Limited information is currently available for trace element concentrations in the tissues of the $P$. aequinoctalis with, to the best of our knowledge, only three studies reported such levels for feathers (Blévin et al. 2013), for soft tissues (Anderson et al., 2010) and for both (Stewart et al., 1999). The concentrations of trace elements in liver and kidney of $P$. aequinoctialis from Kerguelen waters were overall in the same order of magnitude than those reported for $P$. aequinoctialis collected in 1995 and 1996 as bycatch of tuna fisheries around New Zealand (Stewart et al., 1999). Moreover, it presents the same distribution pattern between liver and kidney tissues for all elements (except Se which was not analysed by these authors). However, $\mathrm{Hg}$ concentrations in the feathers of adult birds from the present study were obviously higher (4.2 times) than those in chicks from the same location as a result of longer term exposure in adults (Blévin et al. 2013).

In birds from Kerguelen waters, $\mathrm{Cu}$ concentrations in feathers were half those of $P$. aequinoctialis collected in Bird Island, South Georgia, during the 2001/02 austral summer (Anderson et al., 2010). In contrast, $\mathrm{Zn}$ values from the present study were 1.5 times higher when compared to Bird Island seabirds. Even though trace elements contamination is known to have several deleterious effects in birds testis (Scheuhammer, 1987), data for analyses of such tissue is scarce. Kim et al. (1998) present data with similar distribution and, in a general 
way, within the same orders of magnitude as the present work. Elevated $\mathrm{Cu}$ variation in this tissue might be linked to body condition, as suggested by Malinga et al. (2010). These authors also suggested that the variation of $\mathrm{Cu}$ concentrations could be due to different stages of development of the gonads, which was visually confirmed in the present study. More generally, sex might play a role in trace element distribution in some seabird species (Kim et al., 1998). Sexual size dimorphism or different age composition in each gender (see Bugoni and Furness, 2009) could affect contaminant levels, but the main driving sex-related factor is the excretion of potentially toxic materials into the egg that reduce the contaminant burdens of breeding females (Stewart et al., 1999). Combined to the different turnover rates of the different tissues, it is most likely that the significantly higher $\mathrm{Cd}$ muscle concentrations in males than in females of white-chinned petrels from the Kerguelen waters could be explained by the muscle turnover possibly matching the egg laying period, since it is long known that this tissue has a slower turnover rate than liver (Hobson \& Clark, 1992). Moreover, no dilution with growth or emaciation effect was detected, as previously stated. So, further discussion considers the whole grouped dataset, with no sex separation.

\section{Influence of trophic ecology on trace element concentrations}

Stewart et al. (1999) classified procellariiform seabirds in function of their pattern of accumulation of $\mathrm{Hg}$ in the liver and $\mathrm{Cd}$ in the kidney. White-chinned petrels from Kerguelen fall into the same category as Procellaria petrels (including the white-chinned petrel) from New Zealand that are characterized by moderately high liver $\mathrm{Hg}$ and high kidney $\mathrm{Cd}$ concentrations. No significant relationship between liver $\mathrm{Hg}$ and kidney $\mathrm{Cd}$ was found, which can be attributed to the distinctive biochemistry of the two metals (Stewart et al. 1999). Elevated $\mathrm{Hg}$ concentrations in the tissues of $P$. aequinoctialis are likely due to the presence of mesopelagic prey in its diet that is mainly composed of fish and cephalopods in Kerguelen 
waters (66 and $17 \%$ by mass, respectively; Delord et al., 2010). In marine predators, trophic position is not always the main factor in determining $\mathrm{Hg}$ concentrations, because mesopelagic prey was shown to increase disproportionately their Hg burdens (Ochoa-acuña et al., 2002; Thompson et al., 1998). Indeed, mesopelagic fish have elevated $\mathrm{Hg}$ concentrations as the result of enhanced $\mathrm{Hg}$ methylation in deep waters (Chouvelon et al., 2012; Monteiro et al., 1996). Cephalopods can also be considered as an important predator $\mathrm{Hg}$ source since they mainly contain $\mathrm{Hg}$ under organic forms, which is highly bioavailable for the upper trophic levels (Bustamante et al., 2006). Long-term $\mathrm{Hg}$ exposure of $P$. aequinoctalis population from Kerguelen waters is also influenced by the species feeding habits outside the breeding period. For instance, $P$. aequinoctalis winters in the Benguela current, with associated dietary changes (Jackson, 1988). In this area, fish is still the main prey class (73\% by mass), but it includes an important proportion (36\%) of offal, mainly fish heads and guts discarded by fishing vessels that keep aboard the commercially interesting part, i.e. the muscle. Muscle is one of the main tissues in fish with the lowest concentrations of trace elements (except $\mathrm{Hg}$ and arsenic; Bustamante et al., 2003; Kojadinovic et al., 2007; Metian et al., 2013). Because trace element concentrations in muscle are below concentrations in the whole fish, the consumption of offal could represent a higher intake of trace elements, especially $\mathrm{Cd}$. In Kerguelen fish, liver contains up to $87 \%$ of the whole $\mathrm{Cd}$ body burden with concentrations $>10 \mu \mathrm{g} \mathrm{g}^{-1} \mathrm{dw}$ (Bustamante et al. 2003). Therefore, interactions with fisheries both during and outside the breeding season would lead to an increase intake of $\mathrm{Cd}$ in addition to $\mathrm{Cd}$ contamination resulting from squid consumption (Bustamante et al., 1998a; Muirhead and Furness, 1988). Indeed, Cd levels in P.aequinoctalis tissues were in the same range as those of species with a higher proportion of cephalopods in their diets, such as albatrosses. For example, the Laysan albatross (Phoebastria immutabilis) presents average renal Cd levels of $59.7 \mu \mathrm{g} \mathrm{g}^{-1} \mathrm{dw}$ (Honda et al., 1990) and Southern Ocean albatrosses (Diomedea exulans, D. 
epomorpha, D. cauta, D. bulleri and D. melanophris) show renal Cd levels ranging from 74 to $132 \mu \mathrm{g} \mathrm{g}^{-1} \mathrm{dw}$ (Stewart et al. 1999). Crustaceans are also likely to contribute to Cd exposure in $P$. aequinoctalis. For instance, the amphipods Themisto spp. (notably $T$. gaudichaudii) is naturally enriched in Cd (Ritterhoff and Zauke, 1997; Bocher et al., 2003) and may represent a significant source of this element via both direct consumption (Catard et al., 2000; Delord et al., 2010) and secondary ingestion, since this crustacean contributes significantly to the diet of several petrel prey (Anderson et al., 2010). Assuming that offal have a Cd concentration of 10, "natural prey" fish of 0.1 , cephalopods of 25, Themisto spp. of 40 and other crustaceans of $1 \mu \mathrm{g} \mathrm{g}^{-1} \mathrm{dw}$, an estimation of prey contribution in the Benguela waters suggest that cephalopods, offal, crustaceans and natural fish prey would be responsible for approximately $51.8 \%, 43.5 \%, 1.2 \%$ and $0.4 \%$ of the total Cd intake, respectively. Therefore, the hypothesis of offals influencing greatly the birds' Cd levels is likely to be verified. Such calculations were made from diet analysis by mass in the Benguela Region (Jackson, 1988) together with available Cd concentrations of prey from the southern Ocean (Bocher et al., 2003; Bustamante et al., 2003; Ritterhoff \& Zauke, 1997).

Diet is the main pathway of incorporation of non-essential but also essential elements in seabirds. Studies on trace elements in prey showed generally higher values for $\mathrm{Cu}$ and $\mathrm{Zn}$ in cephalopods when compared to mesopelagic fish (Anderson et al., 2010; Bocher et al., 2003; Bustamante et al., 2006a, 2003). Moreover, the antagonism between $\mathrm{Cd}, \mathrm{Cu}$ and $\mathrm{Zn}$ could modify absorption, retention and distribution of the other two (Underwood, 1977). Nevertheless, homeostatic control of internal essential elements plays a major role regulating their absorption in vertebrates, which depends on the individual nutritional requirements (Walsh, 1990). In P. aequinoctalis from the present study, the correlations of $\mathrm{Cu}$ with $\mathrm{Zn}$ would reflect their nutritional status. Thus, low intraspecific variation of $\mathrm{Cu}$ and $\mathrm{Zn}$ concentrations should be expected in the tissues of marine birds in good health. In $P$. 
aequinoctialis from Kerguelen waters, $\mathrm{Cu}$ and $\mathrm{Zn}$ averages were close to the majority of other Kerguelen species (authors' unpublished data), thus highlighting their homeostatic regulation, which is also confirmed by their comparatively low relative standard deviations.

\section{Inter- and intra-tissues relationships between trace elements}

Inter- and intra-tissue correlations between elements reflect the different processes of regulation of essential elements and of detoxification of non essential elements.

In the case of intra-tissue analyses, in the liver, $\mathrm{Cd}$ positively correlated with $\mathrm{Zn}, \mathrm{Se}$ and $\mathrm{Hg}$, and $\mathrm{Hg}$ positively correlated with $\mathrm{Se}$, which is consistent with previous data for procellariiforms seabirds such as the black-footed albatross Diomedea nigripes from Ryukyu Islands (Kim et al., 1998). In regard to $\mathrm{Cd}$ and $\mathrm{Zn}$ co-accumulation, their correlation is likely to reflect $\mathrm{Cd}$ detoxification by metallothioneins (MTs) as already reported for different seabird groups (e.g., Kojadinovic et al., 2007; Ninomiya et al., 2004). Indeed, the great affinity of $\mathrm{Cd}$ for MTs leads to the competition with $\mathrm{Zn}$ for binding sites and to a reduction of the toxic effects of Cd (Klaassen et al., 1999), whereas the Zn displacement would induce MT synthesis, increasing the number of binding sites within the cells. In regard to the coaccumulation of $\mathrm{Hg}$ with $\mathrm{Se}$, their correlation (the highest coefficient found in the whole study) is indicative of $\mathrm{Hg}$ detoxification mechanism involving the biomineralization and storage of non-toxic Se-Hg complex and formation of liver granules when elimination through the feathers cannot match the individual's dietary $\mathrm{Hg}$ intake (Nigro and Leonzio, 1996). Such a process seems to be operative in $P$. aequinoctalis from Kerguelen waters in the liver but not in the kidney (Figure 2).

Moreover, in the kidney, correlation of Se with $\mathrm{Zn}$ could be associated with their interaction in detoxifying processes, even though according to Norheim (1987) Se plays a more important role. Se correlation with $\mathrm{Cu}$ could be inferred from the consumption of some 
crustacean prey, notably E. superba and T. gaudichaudii (see Anderson et al., 2010), since the physico-chemical form in which Se is sequestered by different prey may vary and affect its subsequent bioavailability. Hence, it would appear that intra-specific variation in blood Se concentrations in seabirds most likely reflects individual differences in prey selection (see standard deviation in diet composition in Delord et al., 2010).

Besides $\mathrm{Hg}$, Se is involved in detoxification of other heavy metals such as $\mathrm{Ag}, \mathrm{Cd}$, $\mathrm{Cu}$ and $\mathrm{Zn}$ (Ikemoto et al., 2004). In regard to inter-tissue analyses, Se significant positive correlations between liver, muscle and kidney are probably linked to the detoxifying mechanisms it is involved in, which is corroborated by its significant positive correlation with other elements, notably $\mathrm{Hg}$ in liver and muscle tissues. $\mathrm{Hg}$ significant positive correlation in liver with muscle tissue was already reported for several bird species (e.g. Borgå et al., 2006) and is assumed to result from the bioaccumulation of this element.

The significant positive correlations of $\mathrm{Cd}$ and $\mathrm{Hg}$ in both the liver and kidney confirm the role of these tissues as the main sites for detoxification and long term storage (e.g. Bocher et al., 2003). The negative correlation between $\mathrm{Cd}$ concentrations in liver and $\mathrm{Cd}$ concentrations in feather could be related to a different diet during the non breeding period (higher offal proportion) when moulting normally occurs (Anderson et al., 2010) and in the breeding period, when samples were collected. Indeed, liver has a high protein turnover rate (Cherel et al., 1991) that reflects diet a few days before collection. The $\mathrm{Zn}$ negative correlation between liver and feather could result from the same processes, which is confirmed by its significant correlation with $\mathrm{Cd}$ in the liver. This shift towards liver coaccumulation can happen in periods as short as one or two weeks, as demonstrated by Levengood and Skowron (2007). In other words, Cd and Zn are co-accumulated in the liver (emphasised by the significant intra-tissue correlation) and before being released from the liver to the feathers (emphasised by the negative inter-tissue correlation between liver and 
feathers). Even though, $\mathrm{Zn}$ in feathers presented large variation. This could be due to either molecular interactions between $\mathrm{Cd}, \mathrm{Cu}$, and $\mathrm{Zn}$ or to $\mathrm{Zn}$ affinity for liver metallothioneins (Bocher et al, 2003).

Finally, in regard to the use of feathers as a non destructive monitoring tool, it is noticeable that they presented significant inter-tissue correlation in only two occasions: $\mathrm{Zn}$ and $\mathrm{Cd}$, both with liver and both negative as well. No significant correlation to other trace elements was found for none of the tissues, possibly due to two main factors: firstly, the sampling of the birds occurred in different times of the year and not only that, but consequently in different time shifts in regard to the moult. This might result in a degree of fluctuation in the trace element concentration of the internal tissues and, therefore, the static concentration of the feathers may no longer be correlated to those. The second hypothesised factor is that moult occurs normally during the non breeding period (Anderson et al., 2010), when diet is different (Jackson, 1988), therefore the variation in internal tissues could be enhanced due to a variation in exposure via diet. A further study with birds sampled in a narrower time interval and with a homogenous set of animals in regard to the last moult could better answer the question whether feathers can be used to monitor trace elements in this species and under what conditions.

\section{Acknowledgements}

The authors thank the fieldworkers who helped with collecting the petrels. The present work was supported financially and logistically by the Agence Nationale de la Recherche (program POLARTOP, O. Chastel), the Institut Polaire Français Paul Emile Victor (IPEV, program no.

109, H. Weimerskirch) and the Terres Australes et Antarctiques Françaises (TAAF). C.V.Z. Cipro was supported financially through a post-doctoral grant from the University of La Rochelle and the CNRS (French acronym for National Council of Scientific Research). 


\section{References}

Abdulla, M., Chmielnicka, J., 1990. New aspects on the distribution and metabolism of essential trace elements after dietary exposure to toxic metals. Biological Trace Element Research 23, 25-53.

Agusa, T., Matsumoto, T., Ikemoto, T., Anan, Y., Kubota, R., Yasunaga, G., Kunito, T., Tanabe, S., Ogi, H., Shibata, Y., 2005. Body distribution of trace elements in blacktailed gulls from Rishiri Island, Japan: age-dependent accumulation and transfer to feather and eggs. Environmental Toxicology and Chemistry 24, 2107-2120.

Anderson, O.R.J., Phillips, R.A., Shore, R.F., McGill, R.A.R., McDonald, R.A., Bearhop, S., 2010. Element patterns in albatrosses and petrels: influence of trophic position, foraging range, and prey type. Environmental Pollution 158, 98-107.

Barbraud, C., Delord, K., Marteau, C., Weimerskirch, H., 2009. Estimates of population size of white-chinned petrels and grey petrels at Kerguelen Islands and sensitivity to fisheries. Animal Conservation 12, 258-265.

Barbraud, C., Marteau, C., Ridoux, V., Delord, K., Weimerskirch, H., 2008. Demographic response of a population of white-chinned petrels Procellaria aequinoctialis to climate and longline fishery bycatch. Journal of Applied Ecology 45, 1460-1467.

Berrow, S.D., 2000. Using acoustics to monitor burrownesting white-chinned petrels Procellaria aecquinoctialis at Bird Island, South Georgia. Polar Biol. 23, 575-579.

Birdlife International, 2013. White-chinned Petrel Procellaria aequinoctialis [WWW Document]. Species $\quad$ Factsheet. URL http://www.birdlife.org/datazone/speciesfactsheet.php?id=3922

Blévin, P., Carravieri, A., Jaeger, A., Chastel, O., Bustamante, P., Cherel, Y., 2013. Wide range of mercury contamination in chicks of southern ocean seabirds. PloS one 8, e54508.

Bocher, P., Caurant, F., Miramand, P., Cherel, Y., Bustamante, P., 2003. Influence of the diet on the bioaccumulation of heavy metals in zooplankton-eating petrels at Kerguelen archipelago, Southern Indian Ocean. Polar Biology 26, 759-767.

Borgå, K., Campbell, L., Gabrielsen, G.W., Norstrom, R.J., Muir, D.C.G., Fisk, A.T., 2006. Regional and species specific bioaccumulation of major and trace elements in Arctic seabirds. Environmental Toxicology and Chemistry 25, 2927-36.

Bugoni, L., Furness, R., 2009. Age composition and sexual size dimorphism of albatrosses and petrels off Brazil. Marine Ornithology 260, 253-260.

Bustamante, P., Bertrand, M., Boucaud-Camou, E., Miramand, P., 2006a. Subcellular distribution of $\mathrm{Ag}, \mathrm{Cd}, \mathrm{Co}, \mathrm{Cu}, \mathrm{Fe}, \mathrm{Mn}, \mathrm{Pb}$, and $\mathrm{Zn}$ in the digestive gland of the common cuttlefish Sepia officinalis. Journal of Shellfish ... 25, 987-993.

Bustamante, P., Bocher, P., Cherel, Y., Miramand, P., Caurant, F., 2003. Distribution of trace elements in the tissues of benthic and pelagic fish from the Kerguelen Islands. The Science of the Total Environment 313, 25-39.

Bustamante, P., Caurant, F., Fowler, S.W., Miramand, P., 1998a. Cephalopods as a vector for the transfer of cadmium to top marine predators in the north-east Atlantic Ocean. The Science of the Total Environment 220, 71-80.

Bustamante, P., Cherel, Y., Caurant, F., Miramand, P., 1998b. Cadmium, copper and zinc in octopuses from Kerguelen Islands, Southern Indian Ocean. Polar Biology 19, 264-271.

Bustamante, P., Lahaye, V., Durnez, C., Churlaud, C., Caurant, F., 2006b. Total and organic $\mathrm{Hg}$ concentrations in cephalopods from the North Eastern Atlantic waters: influence of 
geographical origin and feeding ecology. The Science of the Total Environment 368, 585-96.

Carravieri, A., Bustamante, P., Churlaud, C., Cherel, Y., 2013. Penguins as bioindicators of mercury contamination in the Southern Ocean: Birds from the Kerguelen Islands as a case study. The Science of the Total Environment 454-455, 141-8.

Catard, A., Weimerskirch, H., Cherel, Y., 2000. Exploitation of distant Antarctic waters and close shelf-break waters by white-chinned petrels rearing chicks. Marine Ecology Progress Series 194, 249-261.

Cherel, Y., Attaix, D., Rosolowska-Huszcz, D., Belkhou, R., Robin, J.R., Arnal, M., Le Maho, Y., 1991. Whole-body and tissue protein synthesis during brief and prolonged fasting in the rat. Clinical Science 81, 611-619.

Chouvelon, T., Spitz, J., Caurant, F., Mèndez-Fernandez, P., Autier, J., Lassus-Débat, a., Chappuis, a., Bustamante, P., 2012. Enhanced bioaccumulation of mercury in deep-sea fauna from the Bay of Biscay (north-east Atlantic) in relation to trophic positions identified by analysis of carbon and nitrogen stable isotopes. Deep Sea Research Part I: Oceanographic Research Papers 65, 113-124.

Connan, M., Cherel, Y., Mabille, G., Mayzaud, P., 2007. Trophic relationships of whitechinned petrels from Crozet Islands: combined stomach oil and conventional dietary analyses. Marine Biology 152, 95-107.

Coquery, M., Azemard, S., Mora, S., 2001. The analytical performance study for the Medpol region: determination of trace elements and methylmercury in estuarine sediment sample IAEA-405.

Delord, K., Cotté, C., Péron, C., Marteau, C., Pruvost, P., Gasco, N., Duhamel, G., Cherel, Y., Weimerskirch, H., 2010. At-sea distribution and diet of an endangered top predator: relationship between white-chinned petrels and commercial longline fisheries. Endangered Species Research 13, 1-16.

Dietz, R., Noorgard, J., Hansen, J.C., 1998. Have arctic marine mammals adapted to high cadmium levels? Marine Pollution Bulletin 36, 490-492.

Elliott, J., Scheuhammer, A., 1997. Heavy metal and metallothionein concentrations in seabirds from the Pacific coast of Canada. Marine Pollution Bulletin 34, 794-801.

Fitzgerald, W., Engstrom, D., 1998. The case for atmospheric mercury contamination in remote areas. Environmental Science \& Technology 1-7.

Furness, R., Camphuysen, K., 1997. Seabirds as monitors of the marine environment. ICES Journal of Marine Science 54, 726-737.

Gilbertson, M., Elliott, J.E., Peakall, D.B., 1987. Seabirds as indicators of marine pollution, in: Diamond, A.W., Filion, F. (Eds.), The Value of Birds. International Council for Bird Preservation, Cambridge, pp. 231-248.

Goutte, A., Bustamante, P., Barbraud, C., Delord, K., Weimeskirch, H., Chastel, O. 2014. Demographic responses to mercury exposure in two closely-related Antarctic top predators. Ecology DOI: 10.1890/13-1229.1

Hobson, K.A., Clark, R. G., 1992. Assessing avian diets using stable isotopes I: turnover of ${ }^{13} \mathrm{C}$ in tissues. The Condor $94,181-188$.

Honda, K., Marcovecchio, J.E., Kan, S., Tatsukawa, R., Ogi, H., 1990. Metal concentrations in pelagic seabirds from the North Pacific Ocean. Archives of Environmental Contamination and Toxicology 19, 704-11.

Ikemoto, T., Kunito, T., Tanaka, H., Baba, N., Miyazaki, N., Tanabe, S., 2004. Detoxification mechanism of heavy metals in marine mammals and seabirds: interaction of selenium with mercury, silver, copper, zinc, and cadmium in liver. Archives of Environmental Contamination and Toxicology 47, 402-13. 
Jackson, S., 1988. Diets of the white-chinned petrel and sooty shearwater in the southern Benguela region, South Africa. Condor 90, 20-28.

Kim, E., Goto, R., Tanabe, S., 1998. Distribution of 14 elements in tissues and organs of oceanic seabirds. Archives of Environmental Contamination and Toxicology 35, 638645.

Klaassen, C.D., Liu, J., Choudhuri, S., 1999. Metallothionein: an intracellular protein to protect against cadmium toxicity. Annual Review of Pharmacology and Toxicology 39, 267-94.

Kojadinovic, J., Le Corre, M., Cosson, R.P., Bustamante, P., 2007. Trace elements in three marine birds breeding on Reunion Island (Western Indian ocean): part 1-factors influencing their bioaccumulation. Archives of Environmental Contamination and Toxicology 52, 418-30.

Levengood, J.M., Skowron, L.M., 2007. Coaccumulation of cadmium and zinc in tissues of sentinel mallards (Anas platyrhynchos) using a former dredge-disposal impoundment. Archives of Environmental Contamination and Toxicology 53, 281-6.

Mailman, R.B., 1980. Heavy metals, in: Perry, J.J. (Ed.), Introduction to Environmental Toxicology. Elsevier, New York, pp. 34-43.

Malinga, M., Szefer, P., Gabrielsen, G.W., 2010. Age, sex and spatial dependent variations in heavy metals levels in the Glaucous Gulls (Larus hyperboreus) from the Bjørnøya and Jan Mayen, Arctic. Environmental Monitoring and Assessment 169, 407-16.

Metian, M., Warnau, M., Chouvelon, T., Pedraza, F., Rodriguez Y Baena, A.M., Bustamante, P., 2013. Trace element bioaccumulation in reef fish from New Caledonia: Influence of trophic groups and risk assessment for consumers. Marine Environmental Research 8788, 26-36.

Monteiro, L., Furness, R., 1995. Seabirds as monitors of mercury in the marine environment. Water, Air and Soil Pollution 80, 851-870.

Monteiro, L.R., Costa, V., Furness, R.W., Santos, R.S., 1996. Mercury concentrations in prey fish indicate enhanced bioaccumulation in mesopelagic environments. Marine Ecology Progress Series 141, 21-25.

Muirhead, S.., Furness, R.., 1988. Heavy metal concentrations in the tissues of seabirds from Gough Island, South Atlantic Ocean. Marine Pollution Bulletin 19, 278-283.

Nigro, M., Leonzio, C., 1996. Intracellular storage of mercury and selenium in different marine vertebrates. Marine Ecology Progress Series 135, 137-143.

Ninomiya, R., Koizumi, N., Murata, K., 2004. Metal concentrations in the liver and kidney of aquatic mammals and penguins. Biological Trace Element Research 97, 135-48.

Norheim, G., 1987. Levels and interactions of heavy metals in sea birds from Svalbard and the Antarctic. Environmental Pollution 47, 83-94.

Ochoa-acuña, H., Sepúlveda, M.S., Gross, T.S., 2002. Mercury in feathers from Chilean birds: influence of location, feeding strategy, and taxonomic affiliation. Marine Pollution Bulletin 44, 340-5.

Péron, C., Delord, K., Phillips, R.A., Charbonnier, Y., Marteau, C., Louzao, M., Weimerskirch, H., 2010. Seasonal variation in oceanographic habitat and behaviour of white-chinned petrels Procellaria aequinoctialis from Kerguelen Island. Marine Ecology Progress Series 416, 267-284.

Ridoux, V., 1994. The diets and dietary segregation of seabirds at the subantarctic Crozet Islands (part 1). Marine Ornithology 22, 1-64.

Ritterhoff, J., Zauke, G.-P., 1997. Influence of body length, life-history status and sex on trace metal concentrations in selected zooplankton collectives from the Greenland Sea. Marine Pollution Bulletin 34, 614-621. 
Scheuhammer, A. M., 1987. The chronic toxicity of aluminium, cadmium, mercury, and lead in birds: a review. Environmental pollution (Barking, Essex : 1987) 46, 263-95.

Scheuhammer, A.M., Meyer, M.W., Sandheinrich, M.B., Murray, M.W., 2007. Effects of environmental methylmercury on the health of wild birds, mammals, and fish. Ambio 36, $12-18$.

Selin, N.E., 2009. Global Biogeochemical Cycling of Mercury: A Review. Annual Review of Environment and Resources 34, 43-63.

Stewart, F., Phillips, R., Bartle, J., 1999. Influence of phylogeny, diet, moult schedule and sex on heavy metal concentrations in New Zealand Procellariiformes. Marine Ecology Progress Series 178, 295-305.

Tartu, S., Goutte, A., Bustamante, P., Angelier, F., Moe, B., Clément-Chastel, C., Bech, C., Gabrielsen, G.W., Bustness, J.O., Chastel, O., 2013. To breed or not to breed: endocrine response to mercury contamination by an arctic seabird. Biology Letters 9(4), 20130317.

Tan, S.W., Meiller, J.C., Mahaffey, K.R., 2009. The endocrine effects of mercury in humans and wildlife. Critical Reviews in Toxicology 39, 228-69.

Thompson, D.R., Furness, R.W., Monteiro, L.R., 1998. Seabirds as biomonitors of mercury inputs to epipelagic and mesopelagic marine food chains. Science of The Total Environment 213, 299-305.

Underwood, E.J., 1977. Trace elements in human and animal nutrition, Academic. ed. New York.

Walsh, P.M., 1990. The use of seabirds as monitors of heavy metals in the marine environment, in: Furness, R.W., Rainbow, P.S. (Eds.), Heavy Metals in the Marine Environment. CRC, New York, pp. 183-204. 


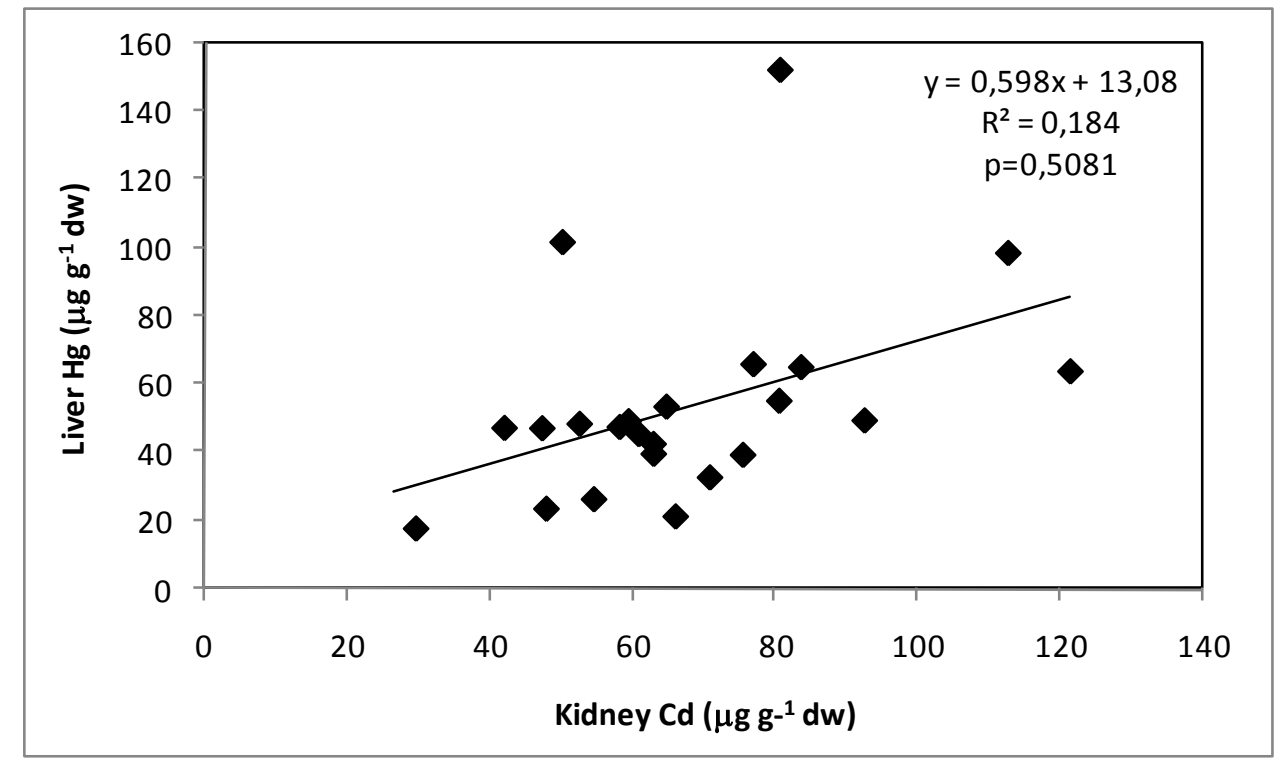

Figure 1 - Concentrations of liver $\mathrm{Hg}$ versus kidney $\mathrm{Cd}\left(\mu \mathrm{g} \cdot \mathrm{g}^{-1} \mathrm{dw}\right)$ in white-chinned petrels $P$. aequinoctialis from Kerguelen waters. 


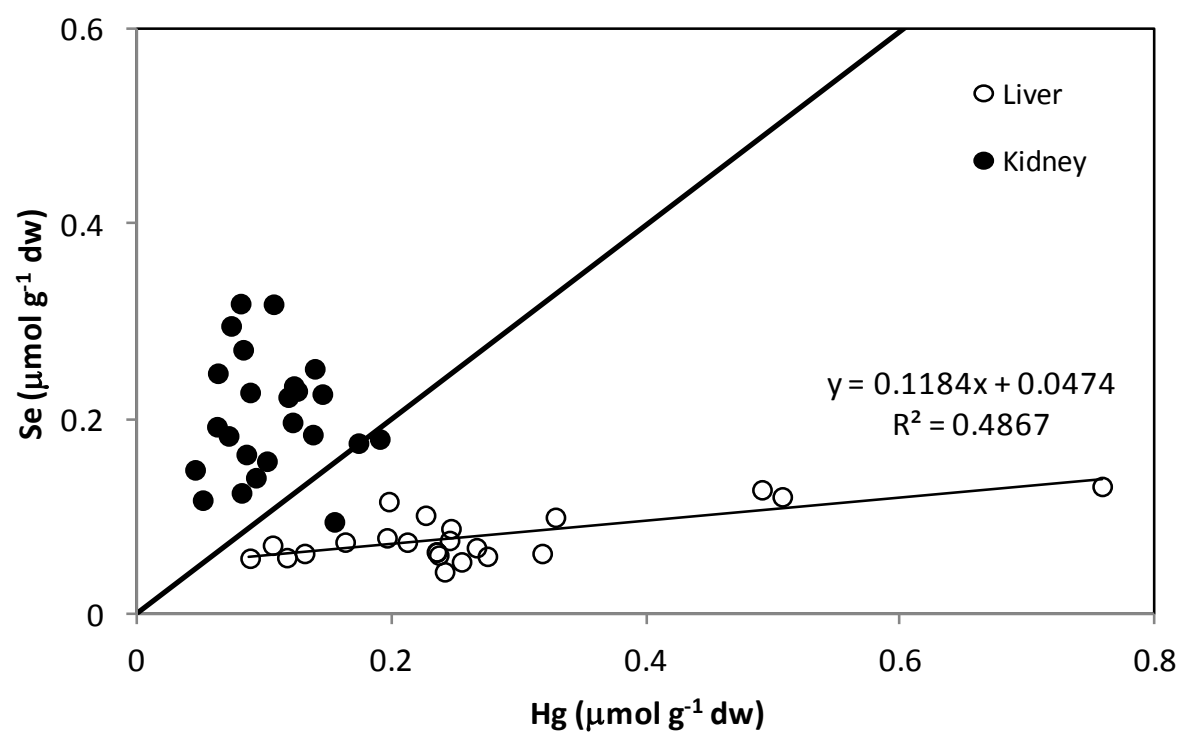

Figure 2 - Se and $\mathrm{Hg}$ molar concentrations $\left(\mu \mathrm{mol} \mathrm{g}^{-1} \mathrm{dw}\right.$ ) in liver and kidney of whitechinned petrels $P$. aequinoctialis from Kerguelen waters. Bold line indicates the 1:1 molar ratio. 
Table 1 - Trace element concentrations (mean \pm SD and range; $\mu \mathrm{g} \cdot \mathrm{g}^{-1} \mathrm{dw}$ ) in tissues of whitechinned petrels $P$. aequinoctialis from Kerguelen waters. Sampling numbers are given accordingly.

\begin{tabular}{|c|c|c|c|c|c|c|c|c|c|c|}
\hline Tissue & $\mathrm{n}$ & $\mathrm{Cd}$ & $\mathrm{n}$ & $\mathrm{Cu}$ & $\mathrm{n}$ & $\mathrm{Hg}$ & $\mathrm{n}$ & $\mathrm{Se}$ & $\mathrm{n}$ & $\mathrm{Zn}$ \\
\hline \multirow[t]{2}{*}{ Kidney } & 29 & $65.7 \pm 22.2$ & 29 & $15.6 \pm 4.4$ & 27 & $23.6 \pm 15.5$ & 24 & $16.1 \pm 4.8$ & 29 & $131 \pm 23$ \\
\hline & & $26.4-121$ & & $11.8-35.7$ & & $8.91-91.8$ & & $7.5-25.2$ & & $96-200$ \\
\hline \multirow[t]{2}{*}{ Liver } & 26 & $20.5 \pm 6.5$ & 26 & $16.2 \pm 4.6$ & 26 & $58.4 \pm 33.4$ & 23 & $6.2 \pm 2.0$ & 26 & $127 \pm 31$ \\
\hline & & $7.43-37.0$ & & $10.6-31.8$ & & $17.6-152$ & & $3.4-10.4$ & & $80-193$ \\
\hline \multirow[t]{2}{*}{ Muscle } & 32 & $1.80 \pm 0.82$ & 32 & $12.0 \pm 2.2$ & 32 & $2.86 \pm 0.80$ & 31 & $9.7 \pm 3.4$ & 32 & $80 \pm 24$ \\
\hline & & $0.86-4.04$ & & $8.2-15.7$ & & $1.28-4.54$ & & $5.3-21.0$ & & $54-134$ \\
\hline \multirow[t]{2}{*}{ Feather } & 22 & $0.66 \pm 0.39$ & 22 & $6.0 \pm 2.6$ & 22 & $7.63 \pm 3.87$ & - & - & 22 & $196 \pm 143$ \\
\hline & & $0.18-1.53$ & & $2.8-11.8$ & & $2.30-14.2$ & & & & $100-797$ \\
\hline \multirow[t]{2}{*}{ Testis } & 3 & $42.7 \pm 14.4$ & 3 & $19.2 \pm 13.7$ & - & - & - & - & 3 & $145 \pm 15$ \\
\hline & & $30.8-58.8$ & & $11.3-35.0$ & & & & & & $128-156$ \\
\hline
\end{tabular}


Table 2 - Correlation (Pearson's product-moment correlation coefficient) matrix for intra- and inter-tissue comparisons. Significant values at $\alpha=0.05$ are bold and asterisk marked.

\begin{tabular}{|c|c|c|c|c|c|c|c|c|c|c|}
\hline & $\overline{C d}$ & $\overline{\mathrm{Cu}}$ & $\mathrm{Hg}$ & $\mathrm{Se}$ & $\mathrm{Zn}$ & & kidney & liver & muscle & feather \\
\hline Kidney & & & & & & $C d$ & & & & \\
\hline $\mathrm{Cd}$ & 1 & & & & & kidney & 1 & & & \\
\hline $\mathrm{Cu}$ & -0.244 & 1 & & & & liver & $0.650^{*}$ & 1 & & \\
\hline $\mathrm{Hg}$ & 0.044 & -0.070 & 1 & & & muscle & 0.387 & 0.332 & 1 & \\
\hline $\mathrm{Se}$ & $0.413^{*}$ & $0.399^{*}$ & -0.051 & 1 & & feather & -0.100 & $-0.635^{\star}$ & -0.188 & 1 \\
\hline $\mathrm{Zn}$ & $0.382^{*}$ & $0.624^{\star}$ & 0.063 & $0.552^{\star}$ & 1 & & & & & \\
\hline Liver & & & & & & $\begin{array}{c}\mathrm{Cu} \\
\text { kidney }\end{array}$ & 1 & & & \\
\hline $\mathrm{Cd}$ & 1 & & & & & liver & 0.320 & 1 & & \\
\hline $\mathrm{Cu}$ & 0.184 & 1 & & & & muscle & -0.334 & 0.480 & 1 & \\
\hline $\mathrm{Hg}$ & $0.435^{\star}$ & -0.244 & 1 & & & feather & 0.029 & -0.232 & 0.168 & 1 \\
\hline $\mathrm{Se}$ & $0.607^{\star}$ & 0.048 & $0.698^{*}$ & 1 & & & & & & \\
\hline $\mathrm{Zn}$ & $0.533^{\star}$ & $0.525^{\star}$ & 0.194 & 0.328 & 1 & 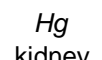 & 1 & & & \\
\hline Muscle & & & & & & liver & $0.584^{\star}$ & 1 & & \\
\hline $\mathrm{Cd}$ & 1 & & & & & muscle & 0.419 & $0.579^{*}$ & 1 & \\
\hline $\mathrm{Cu}$ & 0.236 & 1 & & & & feather & 0.143 & 0.053 & -0.119 & 1 \\
\hline $\mathrm{Hg}$ & -0.098 & -0.050 & 1 & & & & & & & \\
\hline $\mathrm{Se}$ & 0.090 & 0.244 & $0.469^{*}$ & 1 & & $\mathrm{Se}$ & & & & \\
\hline $\mathrm{Zn}$ & -0.164 & $-0.663^{\star}$ & -0.107 & -0.225 & 1 & $\begin{array}{l}\text { kidney } \\
\text { liver }\end{array}$ & $\begin{array}{c}1 \\
0.519^{*}\end{array}$ & 1 & & \\
\hline Feather & & & & & & muscle & $0.652^{\star}$ & $0.728^{\star}$ & 1 & \\
\hline $\mathrm{Cd}$ & 1 & & & & & feather & - & - & - & 1 \\
\hline $\mathrm{Cu}$ & 0.420 & 1 & & & & & & & & \\
\hline $\mathrm{Hg}$ & -0.286 & -0.135 & 1 & & & $Z n$ & & & & \\
\hline $\mathrm{Se}$ & - & - & - & 1 & & kidney & 1 & & & \\
\hline \multirow[t]{3}{*}{$\mathrm{Zn}$} & 0.005 & -0.038 & 0.290 & - & 1 & liver & 0.296 & 1 & & \\
\hline & & & & & & muscle & 0.031 & -0.259 & 1 & \\
\hline & & & & & & feather & -0.316 & $-0.547^{\star}$ & 0.352 & 1 \\
\hline
\end{tabular}

